\title{
Thermal characteristics of the combustion process of biomass and sewage sludge
}

\author{
Aneta Magdziarz $\cdot$ Małgorzata Wilk
}

Received: 2 July 2012 / Accepted: 21 December 2012/Published online: 12 February 2013

(C) The Author(s) 2013. This article is published with open access at Springerlink.com

\begin{abstract}
The combustion of two kinds of biomass and sewage sludge was studied. The biomass fuels were wood biomass (pellets) and agriculture biomass (oat). The sewage sludge came from waste water treatment plant. The biomass and sludge percentage in blends with coal were $10 \%$. The studied materials were characterised in terms of their proximate and ultimate analysis and calorific value. The composition of the ash of the studied fuels was also carried out. The behaviour of studied fuels was investigated by thermogravimetric analysis (TG, DTG and DTA). The samples were heated from an ambient temperature up to $1,000{ }^{\circ} \mathrm{C}$ at a constant three rates: 10,40 and $100{ }^{\circ} \mathrm{C} \mathrm{min}{ }^{-1}$ in $40 \mathrm{~mL} \mathrm{~min}^{-1}$ air flow. TG, DTG and DTA analysis showed differences between coal, biomass fuels and sewage sludge. $10 \%$ addition of studied fuels to the mixture with coal changed its combustion profile in the case of sewage sludge addition. The combustion characteristics of fuel mixtures showed, respectively, qualitative summarise behaviour based on single fuels. Evolved gaseous products from the decomposition of studied samples were identified. This study showed that thermogravimetric analysis connected with mass spectrometry is useful techniques to investigate the combustion and co-combustion of biomass fuels, and sewage sludge, together with coal. Nonisothermal kinetic analysis was used to evaluate the Arrhenius activation energy and the pre-exponential factor. The kinetic parameters were calculated using KissingerAkahira-Sunose model.
\end{abstract}

A. Magdziarz $(\bowtie) \cdot$ M. Wilk

Faculty of Metals Engineering and Industrial Computer Science, AGH University of Science and Technology, Al. Mickiewicza 30, 30-059 Kraków, Poland

e-mail: amagdzia@metal.agh.edu.pl
Keywords Biomass - Sewage sludge $\cdot$ Combustion · Thermogravimetric analysis - Mass spectrometry . Kinetic analysis

\section{Introduction}

The development of industry and increasing production, thereby increasing the demand for energy, contributes to the use of energy sources other than conventional ones (coal or natural gas). Atmospheric pollution, which is probably the cause of global warming, enforces an economic policy encouraging alternative energy sources that are less harmful to the environment. Use of renewable energy sources has become a significant element of the energy industry; this is a condition imposed by the European Union. In the last few years, it has not just been Polish and foreign researchers that have become interested in the renewable energy sources problem, an area in which a lot of studies have been conducted [1-5].

Biomass is one of the most available renewable energy sources. Biomass used for energy purposes is mainly wood and wood processing waste, plants derived from energy crops, agricultural products and organic waste, municipal waste and sewage sludge. Biomass is a renewable, $\mathrm{CO}_{2}$ neutral energy resource widely available and increasingly used as an alternative to fossil fuels for energy supply. Combustion is a complex phenomenon involving simultaneous heat and mass transfer with chemical reaction and fluid flow. Using an analogy to coal combustion, the combustion of biomass can be considered as a three stage process: devolatilisation to char and volatiles, and combustion of the volatiles and of the char [6]. The water content is significant and important and in some instances may dominate the biomass combustion process. Pollutant 
emissions generated by combustion are particular matter (PM), $\mathrm{CO}, \mathrm{HC}$, oxides of nitrogen and oxides of sulphur. Nitrogen oxides $\left(\mathrm{NO}_{\mathrm{x}}\right)$ are some of the most important substances resulting from the combustion of fuels. Typical combustion gases contain two kinds of oxides: $\mathrm{NO}$ and $\mathrm{NO}_{2}$. Other kinds of nitrogen oxides are $\mathrm{N}_{2} \mathrm{O}, \mathrm{N}_{2} \mathrm{O}_{3}$ and $\mathrm{N}_{2} \mathrm{O}_{5}$, but they do not play an essential role. Nitrogen oxides are, environmentally, the most harmful substances which is why researches study how to reduce $\mathrm{NO}_{\mathrm{x}}$ emissions. This requires knowledge of the mechanisms of the formation and reduction of $\mathrm{NO}_{\mathrm{x}}$ emissions based on the kinetics of chemical reactions [6]. Carbon oxide is a very harmful substance for living organisms, especially above permissible air emission standards. Carbon oxide, with its property of superseding the oxygen in the oxyhaemoglobin of the blood, forms bonds with the haemoglobin, generating carboxyhaemoglobin leading to suffocation. Sulphur dioxide is considered to be one of the fundamental air pollutants. $\mathrm{SO}_{2}$ is assumed to be the only representative of sulphur oxides in combustion gases (at least $98 \%$ of the total amount of sulphur oxides). During combustion some specific pollutants such as $\mathrm{Cl}_{2}$, $\mathrm{HCl}$, salts, dioxins and furans can occur. The emission of exhaust gases is a significant problem in the combustion of fuels. Numerical simulations using, e.g. CHEMKIN can model of biomass combustion to predict the amount of pollutants generated $\left(\mathrm{NO}_{\mathrm{x}}, \mathrm{CO}, \mathrm{SO}_{2}\right)$ in the exhaust gases coming from boilers [7].

The most problematic, and still under development, is the waste management and utilisation of municipal sewage sludge. The amount of sewage sludge and its physicochemical characteristics is an important problem for the operator of a sewage treatment plant. Sludge treatment processes often, in fact, comprise more than $30 \%$ of the cost of operating the entire waste water treatment plant. Until recently, the problem of sludge management has been little observed and appreciated, and it should be noted that, according to the National Waste Management Plan, in 2008 $\sim 567.3$ thousand $\mathrm{Mg}$ dry mass of sewage sludge was produced $[8,9]$. A significant barrier to its disposal is a high degree of hydration of sludge approaching up to $80 \%$. Municipal sewage sludge is now used for land reclamation, agriculture and the cultivation of plants, some of which is converted into heat and the rest is stored. The latter is the least desirable method of sewage sludge management. According to the National Waste Management Plan, in 2008 of the total mass of sludge produced in municipal waste water treatment plants, almost 92 thousand Mg d.m. (16.1\%) was deposited on Polish territory. Thermal methods require the disposal of sewage sludge drying, stabilization and drainage and preparation of material for the combustion process [10]. Processes of thermal utilisation of sludge can be developed at existing installations (heating plants, power plants or cement plants) or in newly built facilities. There is a large and pressing need for the development of thermal methods for the disposal of sludge. Therefore, thermal processes should be used for the conversion of large quantities of sewage sludge into useful energy. Currently, the new technological solutions are looking for a reduction in $\mathrm{CO}_{2}, \mathrm{NO}_{\mathrm{x}}$ and $\mathrm{SO}_{\mathrm{x}}$ emissions from energy processes. The co-combustion of biomass with coal is a promising application. In the literature, there are some recent works on the co-combustion of biomass, sewage sludge and coal [11-16].

Combustion characteristics of biomass fuels, as well as sewage sludge, have been studied widely using thermoanalytical techniques. The advantages of thermogravimetric analysis are its rapid assessment of the fuel value, the temperatures at which combustion starts and ends, and other characteristics such as maximum reactivity temperature, ash amount and total combustion time. Thermogravimetric analysis is very useful for studying the kinetics of combustion processes [17-25]. Thermal methods such as TG, DTG and DTA have been used for studying a variety of areas of combustion. Thermal analysis (TA) determines a set of methods for study of the selected physical properties of the substance under the influence of temperature. Sometimes, simultaneously, the environment (pressure, atmosphere chemical composition) can be changed. Thermogravimetry (TG) is a technique which monitors the sample mass as a function of temperature or time when the sample is subjected to a controlled temperature program. Derivative thermogravimetric (DTG) is based on the rate of mass loss. DTG profiles make it possible to know, for example, the mass loss which is taking place at a temperature during the combustion process. Differential thermal analysis (DTA) enables measuring the thermal effects during the studied process. The obtained peaks correspond with exothermal or endothermal effects. An investigation of gaseous products generated during the heating of sewage sludge material has not been done in wide range as coal or biomass because of its complex composition. This kind of information could help to explain the behaviours of the examined process. To complete thermal research on combustion processes, the mass spectrometry method is necessary. The use of TG and MS techniques allows characterising of gaseous products generated by thermal decomposition in real-time analysis.

The objective of this study has been to study the combustion of biomass and municipal sewage sludge and their co-combustion with coal by TA (TG/DTG/DTA). The results obtained from thermogravimetric analysis were elaborated according to the Kissinger-Akahira-Sunose model. The activation energy and pre-exponential factor were calculated. The mass spectrometry technique was used for identification of gaseous pollutants which form during the combustion process, such as $\mathrm{NO}, \mathrm{CO}, \mathrm{CO}_{2}, \mathrm{SO}_{2}$ and $\mathrm{SO}_{3}$. 


\section{Experimental}

Materials

Two kinds of biomass and municipal sewage sludge were used in the experiments for this study. The sample of studied coal was from a Polish coalmine and it is commonly exploited in thermal power stations. The biomass fuels were wood biomass (pellets) and agriculture biomass (oat). These two kinds of biomass were chosen, because of their availability in Poland. Wood biomass in its various forms is available on the energy market. Oats are a grain that are grown in Poland in large quantities. In recent years, there has been a strategy involving the use of oats in the direct combustion for energy production, taking into account that they can be combusted in conventional coalfired boilers. The sewage sludge came from a waste water treatment plant. The biomass and sludge percentage in blends with coal was $10 \%$.

Fuel analysis

Before thermogravimetric analysis, the fuels were analysed to determine the main properties affecting thermal conversion. The proximate and ultimate analyses, as well as the calorific values of the studied samples were determined (Table 1). The properties include volatile matter, ash, moisture content, heating value and chemical composition were tested in accordance with standards (Polish standards: PN-EN 15403, PN-EN 15400, PN-EN 14774, PN-EN 14775). Metal analysis of the fuels was conducted by inductivity coupled plasma spectrometry and spectrophotometry. The metal contents are reported as oxides (Table 2).

\section{Thermogravimetry analysis}

Thermogravimetric analysis was carried out using a Mettler Toledo TG/SDTA 851 apparatus. The TG instrument was calibrated with indium, zinc and aluminium. Its accuracy is equal to $10^{-6} \mathrm{~g}$. For the thermogravimetric analysis (TG/DTG/DTA), the samples were placed in alumina crucible. About $15 \mathrm{mg}$ of sample was heated from an ambient temperature up to $1,000{ }^{\circ} \mathrm{C}$ at a constant three rates: 10,40 and $100{ }^{\circ} \mathrm{C} \mathrm{min}{ }^{-1}$ in $40 \mathrm{~mL} \mathrm{~min}^{-1}$ flow of air. The measurements for each sample had to be done under exactly the same conditions including, for example, the range of temperature, atmosphere, heating rate etc., to determine the most repeatable and precise results. The experiments were replicated to determine their reproducibility, which was found to be very good. TG and DTA curves for each of the fuel samples were obtained as an output. The TG curves represent the instantaneous mass percentage of the tested fuels in contrast to the initial mass.
Table 1 Ultimate and proximate analysis (\%) of the fuels

\begin{tabular}{|c|c|c|c|c|}
\hline & $\begin{array}{l}\text { Wood } \\
\text { biomass }\end{array}$ & Oat & $\begin{array}{l}\text { Sewage } \\
\text { sludge }\end{array}$ & Coal \\
\hline \multicolumn{5}{|l|}{ Proximate analysis } \\
\hline Moisture & 2.9 & 7.1 & 5.3 & 7.8 \\
\hline Ash & 0.3 & 1.5 & 38 & 4.9 \\
\hline \multicolumn{5}{|l|}{ Ultimate analysis $^{\mathrm{db}}$} \\
\hline Carbon & 47.2 & 45.5 & 30.1 & 64.2 \\
\hline Hydrogen & 6.1 & 6.8 & 4.6 & 4.6 \\
\hline Nitrogen & 0.05 & 1.8 & 4.3 & 2.2 \\
\hline Sulphur & 0.02 & 0.15 & 1.2 & - \\
\hline Oxygen by difference & 46.3 & 44.0 & 21.3 & 22.1 \\
\hline \multicolumn{5}{|l|}{ Calorific value $\left(\mathrm{MJ} \mathrm{kg}^{-1}\right)^{\mathrm{db}}$} \\
\hline high heat value (HHV) & 17.59 & 17.20 & 12.24 & 23.53 \\
\hline
\end{tabular}

$d b$ dry basis

Table 2 Ash chemical composition (\%) of the fuels and alkali index

\begin{tabular}{lcrl}
\hline & Wood biomass & \multicolumn{1}{c}{ Oat } & Sewage sludge \\
\hline $\mathrm{SiO}_{2}$ & 12.08 & 21.13 & 25.10 \\
$\mathrm{CaO}$ & 29.06 & 27.94 & 23.53 \\
$\mathrm{MgO}$ & 4.68 & 6.09 & 14.17 \\
$\mathrm{Fe}_{2} \mathrm{O}_{3}$ & 1.57 & 9.31 & 13.81 \\
$\mathrm{Al}_{2} \mathrm{O}_{3}$ & 3.01 & 1.04 & 9.80 \\
$\mathrm{Na}_{2} \mathrm{O}$ & 1.93 & 0.22 & 0.81 \\
$\mathrm{~K}_{2} \mathrm{O}$ & 6.57 & 16.21 & 0.62 \\
$\mathrm{P}_{2} \mathrm{O}_{5}$ & 16.49 & 18.02 & 8.35 \\
$\mathrm{Total}_{2}$ ash components & 75.39 & 99.96 & 96.19 \\
$R_{\mathrm{a} / \mathrm{b}}$ & 2.90 & 2.69 & 1.52 \\
\hline
\end{tabular}

DTA allows for the detection of thermal effects which were accompanied by physical or chemical changes. It consists of recording the temperature difference between the test substance and reference substance (reference) with respect to temperature. The TG, DTG and DTA curves were used in order to assess the thermal characteristics of the fuel samples.

Mass spectrometry analysis

Evolved gaseous products from the decomposition of the studied samples were identified, using a ThermoStar GSD300T Balzers quadruple mass spectrometer (QMS). The mass spectrometer was operated in an electron impact mode (EI) using channeltron as a detector. Screening analyses were performed in a selected-ion monitoring (SIM) mode. The following ions characteristic of each molecules, such as 13, 15, 17, 18, 30, 44, 64, 70 (72) and 80, for $\mathrm{CH}, \mathrm{CH}_{2}, \mathrm{OH}, \mathrm{H}_{2} \mathrm{O}, \mathrm{NO}, \mathrm{CO}_{2}, \mathrm{SO}_{2}, \mathrm{Cl}_{2}$ and $\mathrm{SO}_{3}$, respectively, were monitored. It is important to notice that 
the QMS spectrum of mass 17 can represent not only $\mathrm{NH}_{3}$ but also the $\mathrm{OH}^{-}$fragment of $\mathrm{H}_{2} \mathrm{O}$ fragmentation, and 30 can represent $\mathrm{NO}$ and $\mathrm{C}_{2} \mathrm{H}_{6}$. All of the molecules are gaseous species of particular importance in the combustion process. They are important from the point of view of air pollution as well as energy value.

\section{Kinetic theory}

The most important applications of TA are kinetic investigations. Knowledge of kinetic parameters is one of the ways to determining reaction mechanism in solid phases. The kinetic parameters such as activation energy and preexponential factor could be obtained by methods for analysing non-isothermal solid-state kinetic. Solid-state kinetic data are the major interest in combustion processes (in technological processes to energy production). The kinetic studies of coal, oil and biomass (wood biomass, sewage sludge etc.) combustion has been studied by many research group [12, 23-30]. The most often used methods are FWO, KAS and Kissinger.

Generally, the kinetic of reactions in solid-state are described by equation

$\frac{\mathrm{d} \alpha}{\mathrm{d} t}=k(T) f(\alpha)$,

where $\alpha$ is conversion defined as follows:

$\alpha=\frac{m_{\mathrm{i} 0}-m_{\mathrm{a}}}{m_{\mathrm{i} 0}-m_{\mathrm{f}}}$,

where $m_{\mathrm{i} 0}$ is the initial mass of the sample, $m_{\mathrm{a}}$ is the actual mass and $m_{\mathrm{f}}$ is the mass after combustion.

The rate constant $k$ is determined by the temperature and is given by the Arrhenius equation

$k=A \mathrm{e}^{-\frac{\mathrm{E}_{\mathrm{a}}}{\mathrm{RT}}}$,

where $R$ is the gas constant $\left(8.314 \mathrm{~kJ} \mathrm{~mol}^{-1}\right), T$ is the Kelvin temperature and $A\left(1 \mathrm{~min}^{-1}\right), E_{\mathrm{a}}$ the activation energy $\left(\mathrm{kJ} \mathrm{mol}^{-1}\right)$ are constants that are properties of the material. The combination of these two Eqs. (1) and (3) gives the fundamental expression (4) of analytical methods to calculate kinetic parameters, on the basis of the TG results

$\frac{\mathrm{d} \alpha}{\mathrm{d} t}=A f(\alpha) \mathrm{e}^{-\frac{\mathrm{E}_{a}}{\mathrm{RT}}}$.

The expression of the function $f(\alpha)$ and its derivative $f^{\prime}(\alpha)=$ -1 are used to describe solid-state first-order reaction. The equation including reaction order $n$ takes the form

$\frac{\mathrm{d} \alpha}{\mathrm{d} t}=A(1-\alpha)^{\mathrm{n}} \mathrm{e}^{-\frac{\mathrm{E}_{\mathrm{a}}}{\mathrm{RT}}}$.

For non-isothermal TG experiments at linear heating rate $\beta=\mathrm{d} T / \mathrm{d} t$, Eq. (5) can be written as $\frac{\mathrm{d} \alpha}{\mathrm{d} T}=\frac{A}{\beta}(1-\alpha)^{\mathrm{n}} \mathrm{e}^{-\frac{\mathrm{E}_{\mathrm{a}}}{\mathrm{RT}}}$.

The Eq. (6) express the fraction of materials conversion in the time.

The Kissinger-Akahira-Sunose method is based on the Eq. (7)

$\ln \left(\frac{\beta_{\mathrm{i}}}{T_{\alpha \mathrm{i}}^{2}}\right)=\ln \left(\frac{A_{\alpha} R}{E_{\mathrm{a} \alpha} g(\alpha)}\right)-\frac{E_{\mathrm{a} \alpha}}{R T_{\alpha \mathrm{i}}}$.

The apparent activation energy can be obtained from a plot of $\ln \left(\beta_{\mathrm{i}} / T_{\alpha \mathrm{i}}^{2}\right)$ via $1 / T$ for a given value of conversion $\alpha$, where the slope is equal to $-E_{\mathrm{a}} / R$.

\section{Results and discussion}

Fuels analysis

The proximate and ultimate analyses, as well as the calorific values of the studied samples, are presented in Table 1. As it may be seen, these carbonaceous materials have very different properties, but the main combustible component in the tested materials is carbon. The two kinds of biomass used in this study are wood and oat biomasses. The $\mathrm{C}$ and $\mathrm{H}$ contents of these two kinds of biomass are comparable, as well as their calorific value. Taking into account the chemical composition of sewage sludge some differences are worth mentioning. The $30 \%$ carbon content is two times lower than for coal, and the sulphur content is also lower as compared to coal. The nitrogen content of sewage sludge is the highest among the investigated fuels, so a high $\mathrm{NO}_{x}$ emission could be expected. As for ash, this is about thirty times higher for sewage sludge than for oat or wood biomass. When it comes to calorific values, the energy content is widely higher for biomass than for sewage sludge, as can be seen from the high heat values (HHV). The HHV $\sim 12 \mathrm{MJ} \mathrm{kg}^{-1}$ for sewage sludge is two times lower as compared to coal (the coal used here has an HHV around $25 \mathrm{MJ} \mathrm{kg}^{-1}$ ). Finally, the chemical composition of the investigated materials confirms their relevant properties for the combustion process.

The ash compositions of the studied fuels are presented in Table 2. The chlorines, sulphates and carbonates are not included in the ash balance. The main inorganic elements are $\mathrm{Si}, \mathrm{Ca}, \mathrm{Mg}, \mathrm{Fe}, \mathrm{Al}, \mathrm{Na}$ and $\mathrm{K}$. From Table 2, it can be observed that the principal inorganic constituents are $\mathrm{Si}$, $\mathrm{Ca}, \mathrm{K}, \mathrm{Na}$ and $\mathrm{P}$. The oat and sewage sludge have significantly higher silica content compared to the wood biomass. On the other hand, the content of $\mathrm{P}_{2} \mathrm{O}_{5}$ is very high for wood and oat biomasses. The oat ash includes a very high content of $\mathrm{K}_{2} \mathrm{O}$, but the lowest content of $\mathrm{Na}_{2} \mathrm{O}$. The higher concentration of $\mathrm{Fe}_{2} \mathrm{O}_{3}$ in sewage sludge was 
attributed to the addition of iron compounds used during dewatering in the local sewage sludge treatment plant. Sewage sludge contains, of course, those components that are present in municipal waste and, therefore, trace metals of which levels may be higher than in the raw waste. The sewage sludge ash contains the following trace elements: chromium $(0.083 \%)$, copper $(0.112 \%)$, lead $(0.010 \%)$, mercury $(0.002 \%)$ and nickel $(0.056 \%)$. It should be noted that in the investigated sludge amount of harmful heavy metals is low.

Alkali metals, chlorine and sulphur released during combustion can cause corrosion. The alkali index is an indicator for fouling and slugging. The alkali index expresses the quantity of alkali oxides in the fuel per unit of fuel energy ( $\mathrm{kg}$ alkali $\mathrm{G} / \mathrm{J})$. It is computed as [2]

$(1 / Q) Y_{\mathrm{f}}^{\mathrm{a}}\left(Y_{\mathrm{K}_{2} \mathrm{O}}^{\mathrm{a}}+Y_{\mathrm{Na}_{2} \mathrm{O}}^{\mathrm{a}}\right)$,

$Q$ is the heating value, $\mathrm{GJ} / \mathrm{kg}$ (the value obtained from a bomb calorimeter), $Y_{\mathrm{f}}^{\mathrm{a}}$ is the mass fraction of ash in the fuels, $Y_{\mathrm{K}_{2} \mathrm{O}}^{\mathrm{a}}$ and $Y_{\mathrm{Na}_{2} \mathrm{O}}^{\mathrm{a}}$ are the mass fraction of $\mathrm{K}_{2} \mathrm{O}$ and $\mathrm{Na}_{2} \mathrm{O}$.

Miles and co-workers have suggested that above $0.17 \mathrm{~kg} \mathrm{GJ}^{-1}$ fouling is probable, and above $0.34 \mathrm{~kg} \mathrm{GJ}^{-1}$ fouling is certain to occur. As can be observed, the alkali index estimated for all the fuels are higher than $0.34 \mathrm{~kg} \mathrm{GJ}^{-1}$, which suggest that fouling is certain to occur. Another index using as a measure of the fouling tendency of fuel ash is $R_{\mathrm{b} / \mathrm{a}}$. It is the ratio of the basic metal oxides to the acidic oxides in the ash. It is expressed as [2]

$R_{\mathrm{b} / \mathrm{a}}=\frac{\%\left(\mathrm{Fe}_{2} \mathrm{O}_{3}+\mathrm{CaO}+\mathrm{MgO}+\mathrm{K}_{2} \mathrm{O}+\mathrm{Na}_{2} \mathrm{O}\right)}{\%\left(\mathrm{SiO}_{2}+\mathrm{TiO}_{2}+\mathrm{Al}_{2} \mathrm{O}_{3}\right)}$.

The $R_{\mathrm{b} / \mathrm{a}}$ value increases due to the higher concentration of basic components in the ash; it has a tendency for increased potential for slagging [4]. $R_{\mathrm{b} / \mathrm{a}}$ was calculated without taking into account the content of titanium oxide in the ash. According to the $R_{\mathrm{b} / \mathrm{a}}$ values calculated for the studied fuels, these were as follows in descending order: wood biomass-2.90, oat biomass -2.69 and sewage sludge -1.52 .

Thermogravimetry and mass spectrometry analysis

\section{TG/DTG/MS analysis of fuels}

The characteristics of the TG experiments for combustion of the studied fuels and co-combustion of the fuel mixtures are summarised in Table 3. The temperatures at which the maximum mass loss rate occurs are lower for oat and wood biomasses than for sewage sludge. It is also true to say about temperatures that the maximum mass loss rate increases with the increased heating rate. Figures 1 and 2 show the thermogravimetric (TG) and derivative thermogravimetric (DTG) profiles for wood biomass, oat biomass and sewage sludge. Three samples were heated from ambient temperature to $1,000{ }^{\circ} \mathrm{C}$ at $10{ }^{\circ} \mathrm{C} \mathrm{min}{ }^{-1}$ heating rate. On raising the temperature, combustion of the sample takes place with an associated mass loss, which can be observed in TG and DTG. Comparing the TG curves for all the tested materials, a different character was obtained. The most similar course of TG curves is for wood and oat biomasses. As shown in Fig. 1, the combustion process can be divided into three stages. The first stage corresponded to loss of moisture and very light volatile compounds. The temperature range of the first stage was from ambient temperature to about $200{ }^{\circ} \mathrm{C}$. During this stage, the TG curves for wood biomass, oat biomass and sewage sludge were similar. In the second stage $\left(200-600{ }^{\circ} \mathrm{C}\right)$ a significant drop in mass was observed, caused by the thermal decomposition of hemicellulose, cellulose and lignin in the case of the biomass. Once the temperature was higher than $600{ }^{\circ} \mathrm{C}$ mass loss was brought to an end by thermal decomposition. The end of thermal decomposition of the sewage sludge was above $650{ }^{\circ} \mathrm{C}$.

Mass spectrometry analysis was used to monitor gas emissions, which were identified for all the studied materials. Gaseous emissions upon temperature-programmed combustion in the case of $\mathrm{NO}, \mathrm{SO}_{2}, \mathrm{CO}_{2}$ and $\mathrm{CH}_{4}$ are shown in Figs. 3, 4, 5 and 6. Nitrogen oxides are one of the groups of chemical species that can harm the environment and compromise human heath as $\mathrm{NO}_{x}$ is a primary component of photochemical smog, being partially responsible for corroding metal materials. Two species are identified with $\mathrm{m} / \mathrm{z}$ value: ethane $\mathrm{C}_{2} \mathrm{H}_{6}$ and nitrogen monoxide. In the discussion, it had passed that $\mathrm{m} / \mathrm{z}=30$ correspond to NO. Nitrogen oxide was released during the second stage of combustion of the fuels $\left(200-600{ }^{\circ} \mathrm{C}\right)$. The highest NO concentration was observed during sewage sludge combustion as a consequence of the higher nitrogen content in the material. The $\mathrm{NO}$ emission for sewage sludge shows a close relationship with the combustion process; at c.a. $480{ }^{\circ} \mathrm{C}$ the highest lost mass took place, which corresponds with $\mathrm{NO}$ emission. $\mathrm{SO}_{2}$ is associated with $m / z=64$. The $\mathrm{SO}_{2}$ emission is much lower than the $\mathrm{CO}_{2}$ emission during combustion which may be observed by comparing Figs. 4 and 5. On the other hand, $\mathrm{SO}_{2}$ peaks occur at lower temperatures than $\mathrm{CO}_{2}$ peaks for all the fuels. The highest emission of this compound was noted for coal combustion, a result of the elementary composition of the fuel. Only one $\mathrm{SO}_{2}$ peak was observed at about $432{ }^{\circ} \mathrm{C}$. The $\mathrm{SO}_{2}$ emission for sewage sludge was about eight times lower, but emission of gaseous particle monitored occurred at lower temperatures for sludge than for coal. There were two $\mathrm{SO}_{2}$ peaks, the first at $298{ }^{\circ} \mathrm{C}$ and the second at $461{ }^{\circ} \mathrm{C}$. In the oat and sewage sludge, the $\mathrm{m} / \mathrm{z} 16$ profile exhibits two maximum (Fig. 6). The case of sewage sludge the emission of methane is the highest and takes place at around $490{ }^{\circ} \mathrm{C}$. Figure 7 presented the $\mathrm{Cl}_{2}$ evaluation during heating of studied samples. A relatively 
Table 3 Characteristic parameters obtained from DTG and DTA profiles of studied fuels

\begin{tabular}{|c|c|c|c|c|c|c|c|}
\hline Sample & Heating rate $/{ }^{\circ} \mathrm{C} \min ^{-1}$ & $T_{\mathrm{m}} /{ }^{\circ} \mathrm{C}$ & $\mathrm{DTG}_{\max } / \mathrm{mg} \mathrm{s}^{-1}$ & $\begin{array}{l}\text { Solid residue } \\
\text { char }+ \text { ash }(\%)\end{array}$ & $\mathrm{DTA}_{\max } /{ }^{\circ} \mathrm{C}$ & Main region $/{ }^{\circ} \mathrm{C}$ & mass loss $/ \%$ \\
\hline \multirow[t]{3}{*}{ WB } & 10 & 324 & 0.030 & 1.46 & 455 & $180-632$ & 98 \\
\hline & 40 & 340 & 0.067 & 4.61 & 493 & $180-608$ & 94 \\
\hline & 100 & 345 & 0.215 & 2.10 & 480 & $180-758$ & 97 \\
\hline \multirow[t]{3}{*}{$\mathrm{O}$} & 10 & 295 & 0.036 & 2.75 & 351,482 & $160-688$ & 90 \\
\hline & 40 & 308 & 0.172 & 3.08 & 385,522 & $193-729$ & 88 \\
\hline & 100 & 313 & 0.246 & 4.35 & 533 & $240-695$ & 96 \\
\hline \multirow[t]{3}{*}{ SS } & 10 & 483 & 0.014 & 34.92 & 486 & $161-726$ & 58 \\
\hline & 40 & 287 & 0.026 & 35.41 & 537 & $168-779$ & 56 \\
\hline & 100 & 293 & 0.062 & 37.23 & 549 & $168-828$ & 55 \\
\hline $90 \% \mathrm{C}-10 \% \mathrm{WB}$ & 40 & 513 & 0.031 & 7.26 & 534 & $185-875$ & 84 \\
\hline $90 \% \mathrm{C}-10 \% \mathrm{O}$ & 40 & 520 & 0.027 & 8.69 & 567 & $218-830$ & 92 \\
\hline $90 \% \mathrm{C}-10 \% \mathrm{SS}$ & 40 & 513 & 0.028 & 11.86 & 545 & $292-808$ & 88 \\
\hline
\end{tabular}

Signs of fuels were as follows: $C$ coal, $W B$ wood biomass, $O$ oat, $S S$ sewage sludge; and the mixtures of fuels: $90 \% \mathrm{C}-10 \% \mathrm{WB}, 90 \% \mathrm{C}-10 \%$ O, $90 \% \mathrm{C}-10 \% \mathrm{SS} ; T_{\mathrm{m}}$ temperature of maximum mass loss rate, $D T G_{\max }$ maximum mass loss rate, $D T A_{\max }$ temperature of maximum peak, Main region the temperature intervals of main reaction region and corresponding mass loss

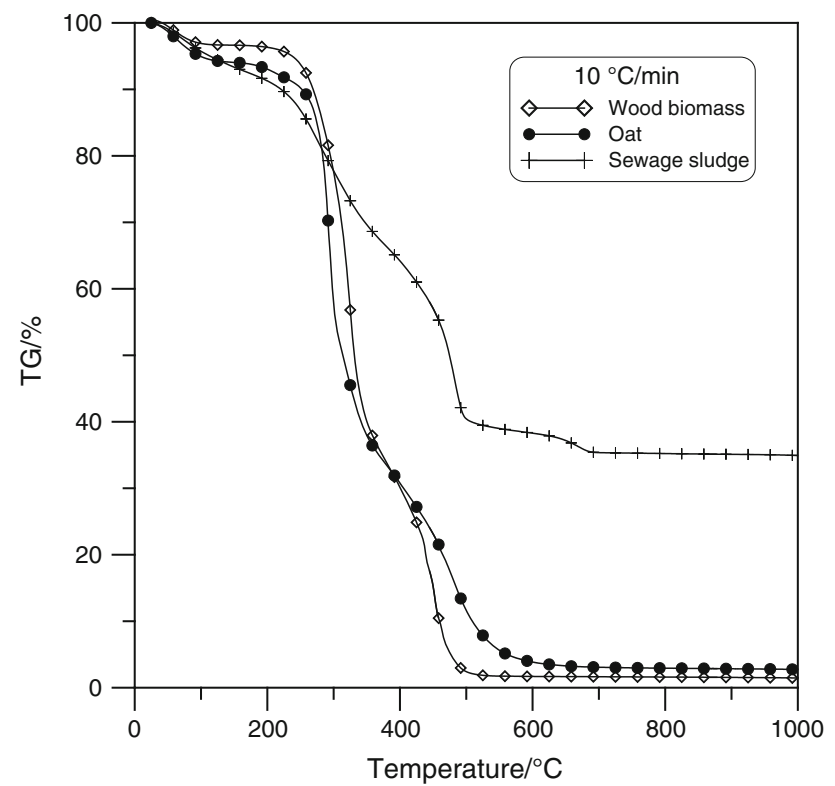

Fig. 1 TG curves for wood biomass, oat biomass and sewage sludge at heating rate $10{ }^{\circ} \mathrm{C} \min ^{-1}$

large amount of $\mathrm{H}_{2} \mathrm{O}(\mathrm{m} / \mathrm{z}=18)$ was formed for oat sample. The lowest temperature peak reflected the moisture of the samples. The $\mathrm{H}_{2} \mathrm{O}$ evaluation profile is similar for wood and oat biomasses, what is the consequence of their similar chemical composition (one maximum peak). For sewage sludge, the $\mathrm{H}_{2} \mathrm{O}$ profile exhibits two visible maxima at around 300 and $474{ }^{\circ} \mathrm{C}$ (Fig. 8).

\section{Effect of heating rate on the combustion process}

The TG results obtained from the temperature-programmed combustions of wood biomass, oat biomass and sewage

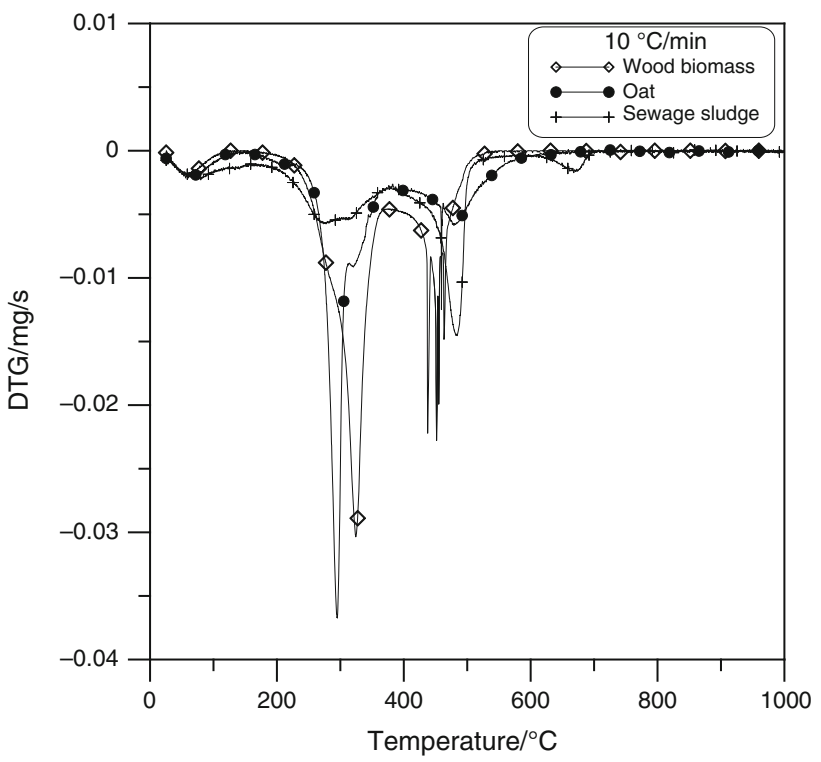

Fig. 2 DTG curves for wood biomass, oat biomass and sewage sludge at heating rate $10{ }^{\circ} \mathrm{C} \mathrm{min}^{-1}$

sludge are shown in Figs. 9, 10 and 11 for the different heating rates used $\left(10,40\right.$ and $\left.100{ }^{\circ} \mathrm{C} \mathrm{min}{ }^{-1}\right)$. With the increase of heating rate, the TG curves are close to each other for all the investigated materials. For wood biomass, the percentage of mass loss is about $98 \%$ at heating rates of 10 and $100{ }^{\circ} \mathrm{C} \mathrm{min}{ }^{-1}$. The maximum mass loss rate was observed at $345{ }^{\circ} \mathrm{C}$ at $100{ }^{\circ} \mathrm{C} \mathrm{min}{ }^{-1}$. On the other hand, the end of the combustion process had taken place at $10{ }^{\circ} \mathrm{C} \min ^{-1}$, and after $500{ }^{\circ} \mathrm{C}$ the mass had no changed. For oats, the heating rate influence was similar. The TG curves are similarly arranged relative to each other. The percentage of sewage sludge mass loss is about $65 \%$ at heating rates of 


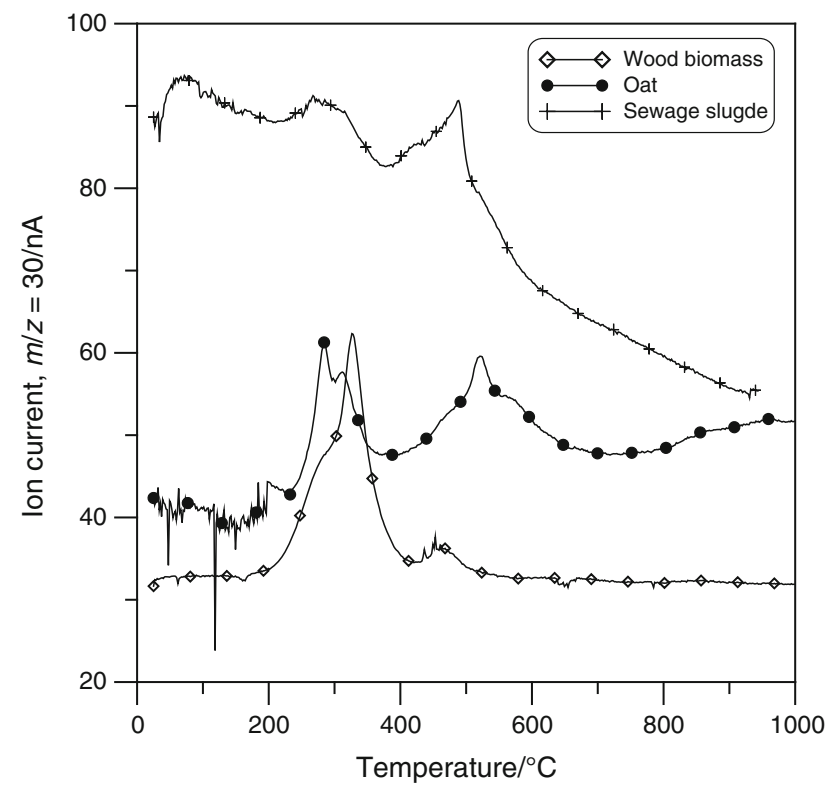

Fig. 3 NO emission by mass spectrometry for wood biomass, oat biomass and sewage sludge at $10{ }^{\circ} \mathrm{C}$ min heating rate under air atmosphere

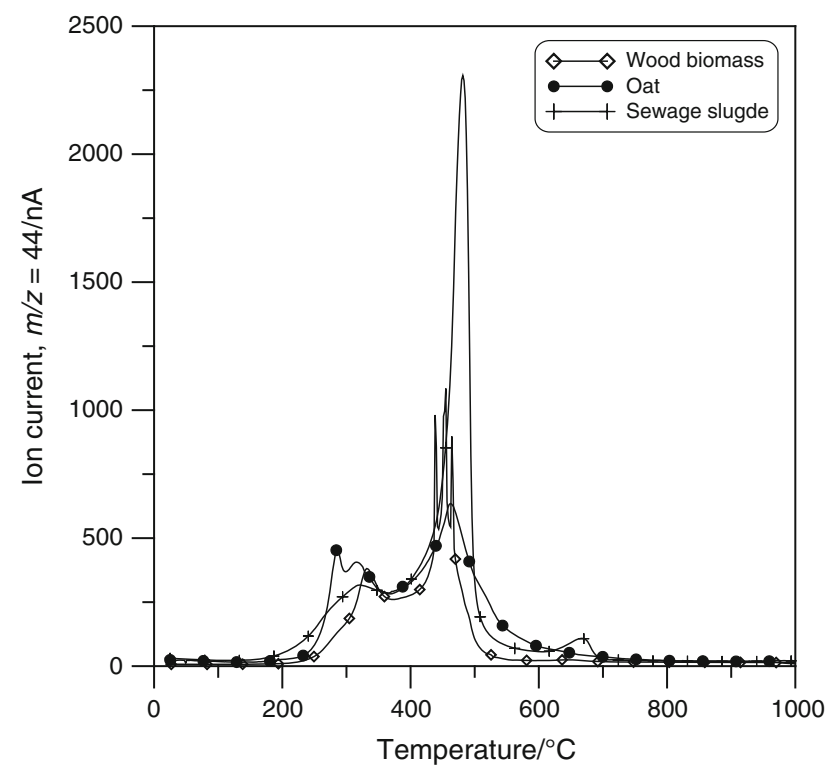

Fig. $4 \mathrm{CO}_{2}$ emission by mass spectrometry for wood biomass, oat biomass and sewage sludge at $10{ }^{\circ} \mathrm{C} \mathrm{min}-1$ heating rate under air atmosphere

10 and $40{ }^{\circ} \mathrm{C} \min ^{-1}$, while about $63 \%$ at $100{ }^{\circ} \mathrm{C} \mathrm{min}^{-1}$, so it can be determined that the heating rate could not affect the residue yield. However, the maximum mass loss rate of the studied fuels increases when the heating rate changes from 10 to $100{ }^{\circ} \mathrm{C} \mathrm{min}^{-1}$, so the heating rate could affect the maximum mass loss rate. The most complicated process (TG curve) was observed for sewage sludge, which is a consequence of its complex chemical composition. The increase of

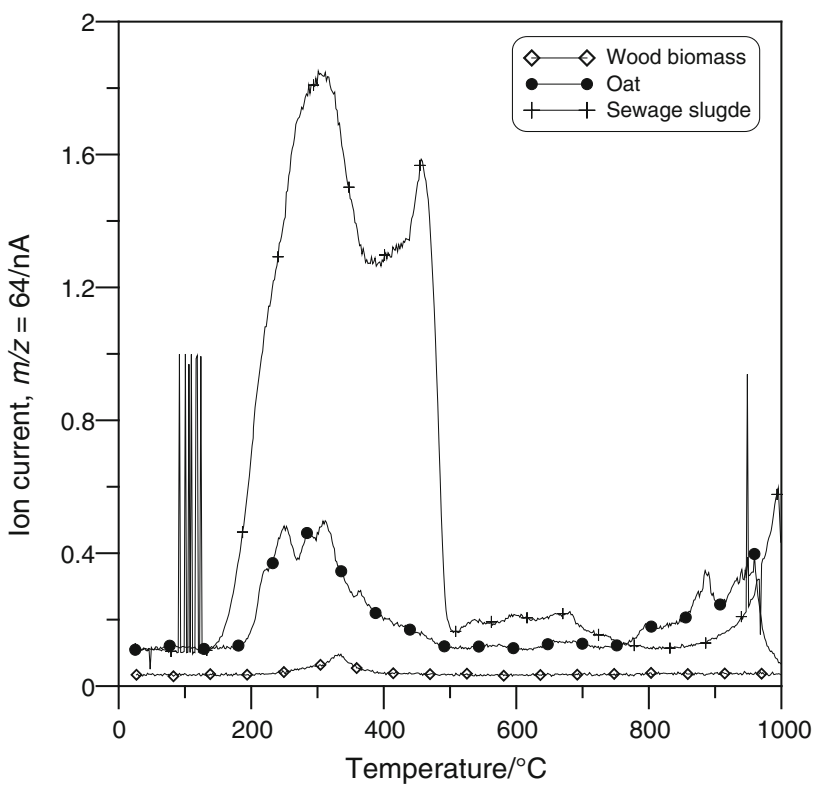

Fig. $5 \mathrm{SO}_{2}$ emission by mass spectrometry for wood biomass, oat biomass and sewage sludge at $10{ }^{\circ} \mathrm{C} \mathrm{min}{ }^{-1}$ heating rate under air atmosphere

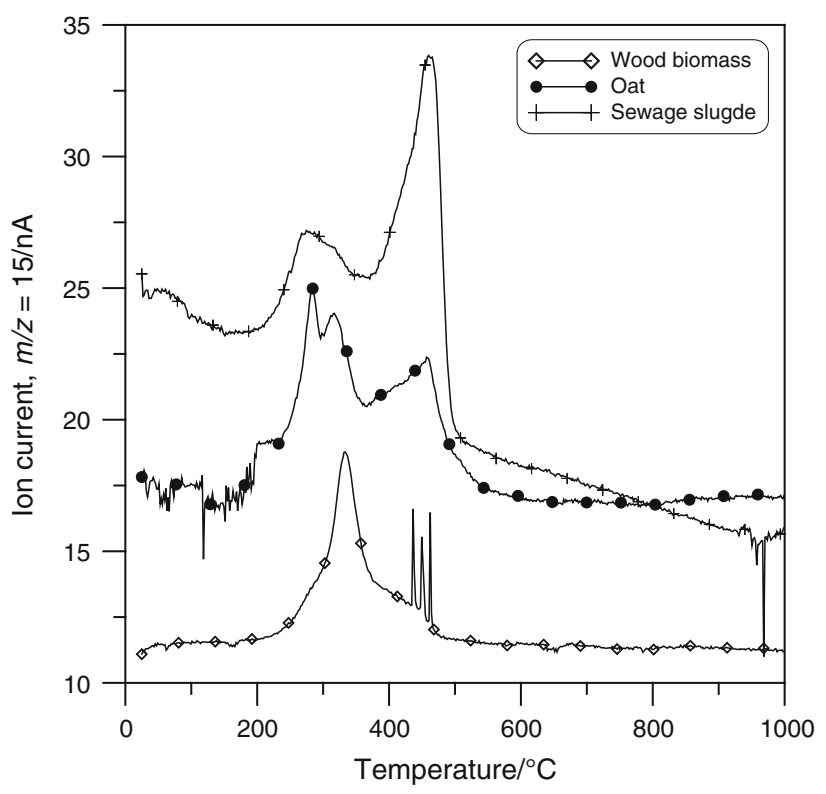

Fig. $6 \mathrm{CH}_{4}$ emission by mass spectrometry for wood biomass, oat biomass and sewage sludge at $10^{\circ} \mathrm{C} \mathrm{min}{ }^{-1}$ heating rate under air atmosphere

heating rate up to $100{ }^{\circ} \mathrm{C}$ caused a shift of the combustion process of all fuels in the direction of higher temperatures.

\section{Co-combustion results of coal and the studied fuels}

Appropriate utilisation of renewable energy sources is an essential element of sustainable development. This utilisation 


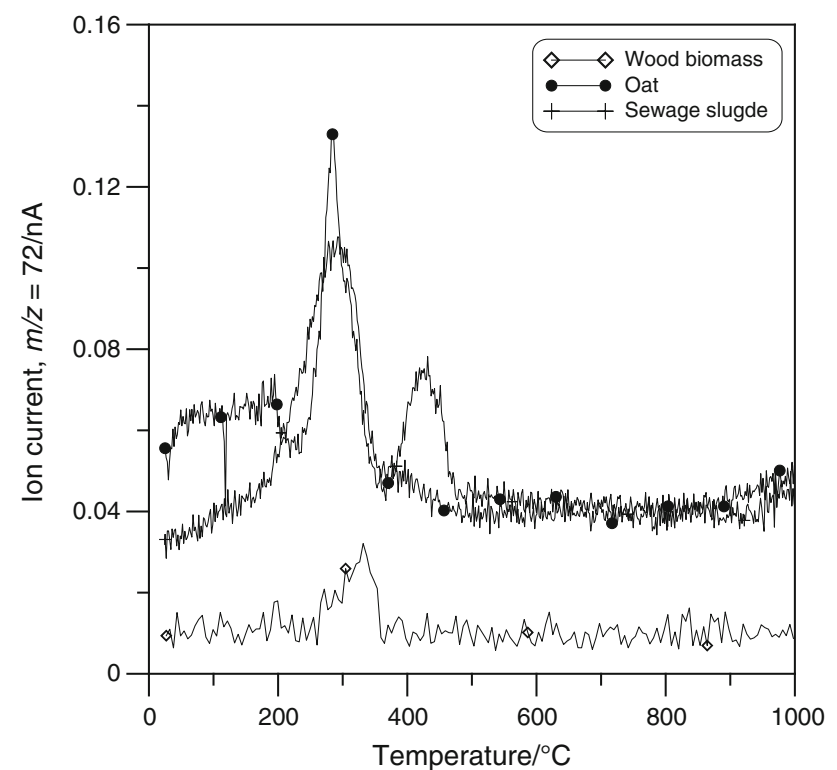

Fig. $7 \mathrm{Cl}_{2}$ emission by mass spectrometry for wood biomass, oat biomass and sewage sludge at $10{ }^{\circ} \mathrm{C} \mathrm{min}{ }^{-1}$ heating rate under air atmosphere

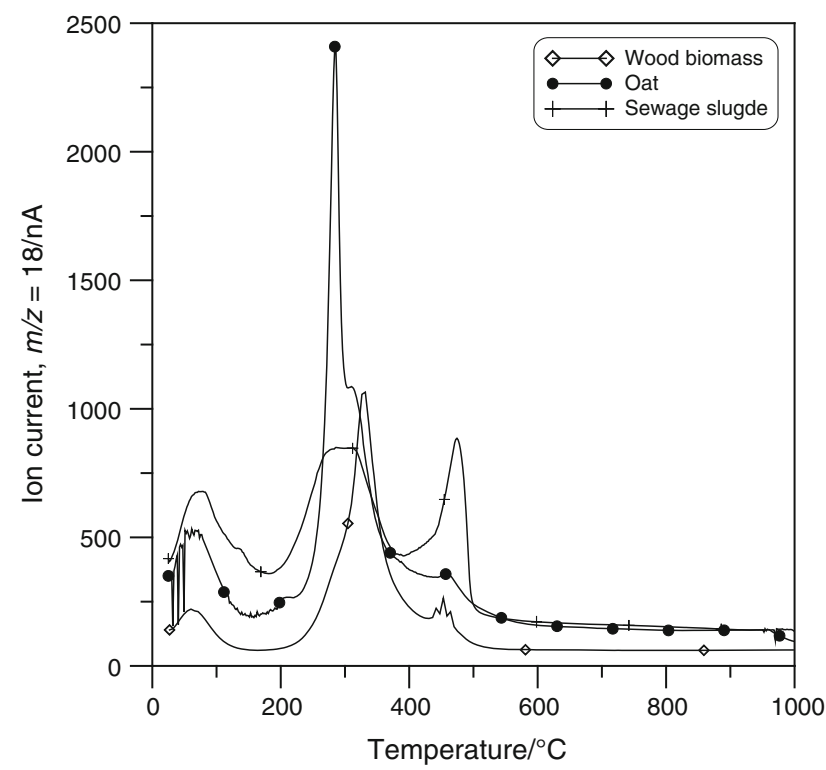

Fig. $8 \mathrm{H}_{2} \mathrm{O}$ emission by mass spectrometry for wood biomass, oat biomass and sewage sludge at $10{ }^{\circ} \mathrm{C} \mathrm{min}{ }^{-1}$ heating rate under air atmosphere

depends on the amount of resources and the technology used. It is estimated that, in Poland, the greatest potential for use is biomass, defined as wood waste from wood production and plant biomass. Currently, there are not many electricitygenerating units based on combustion of biomass. More popular technologies in energy production are the co-combustion of biomass with coal. A growing environmental awareness and legal restrictions for sewage sludge are encouraging the search for appropriate methods of disposal.

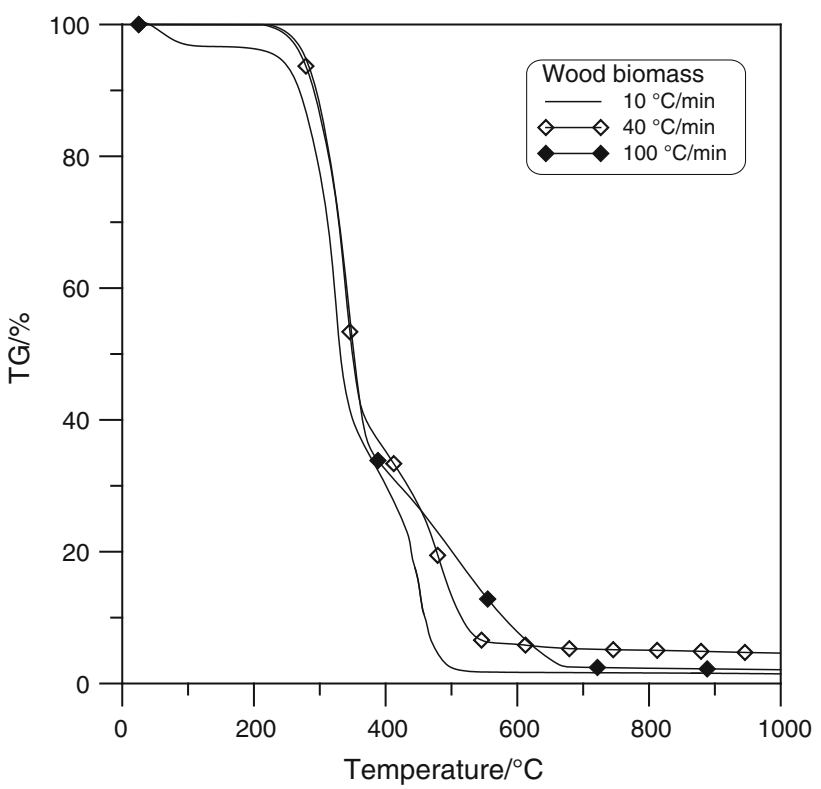

Fig. 9 TG curves for wood biomass at 10,40 and $100{ }^{\circ} \mathrm{C} \mathrm{min}{ }^{-1}$ heating rates

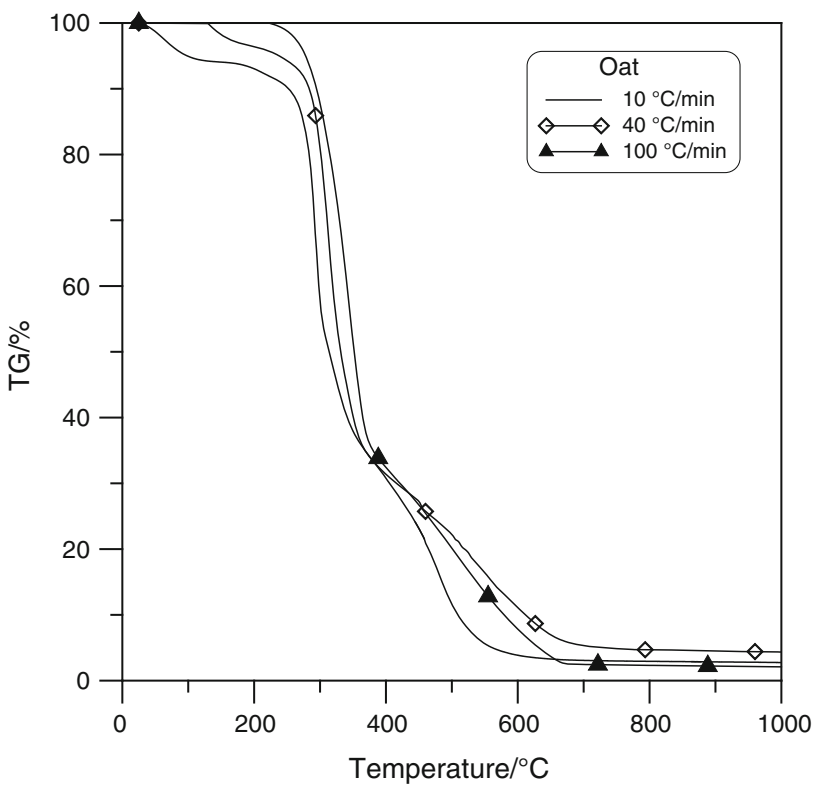

Fig. 10 TG curves for oats at 10,40 and $100{ }^{\circ} \mathrm{C} \min ^{-1}$ heating rates

The combustion of sewage sludge and its blends with coal also combines a number of the advantages, which includes a large reduction in sludge volume. To complete the research on the management of biomass and sewage sludge by their thermal processing, it was also deemed appropriate to investigate their co-combustion with coal. Figures 12 and 13 present the combustion profiles for various mixtures (biomass and sewage sludge with coal). The combustion profile corresponding to coal used in the mixtures is also included as 


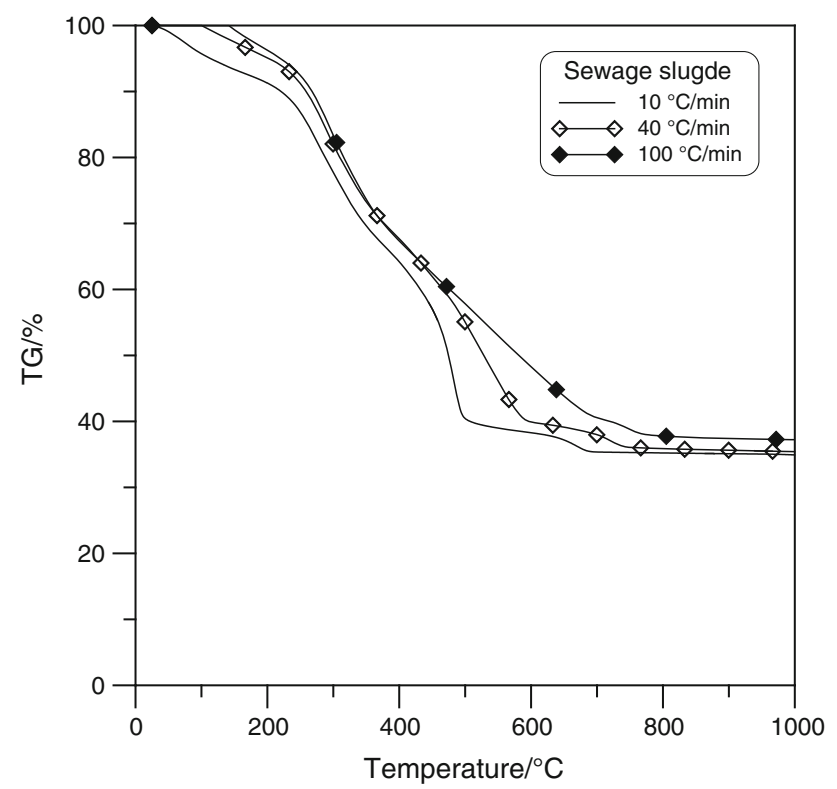

Fig. 11 TG curves for sewage sludge at 10,40 and $100{ }^{\circ} \mathrm{C} \min ^{-1}$ heating rates

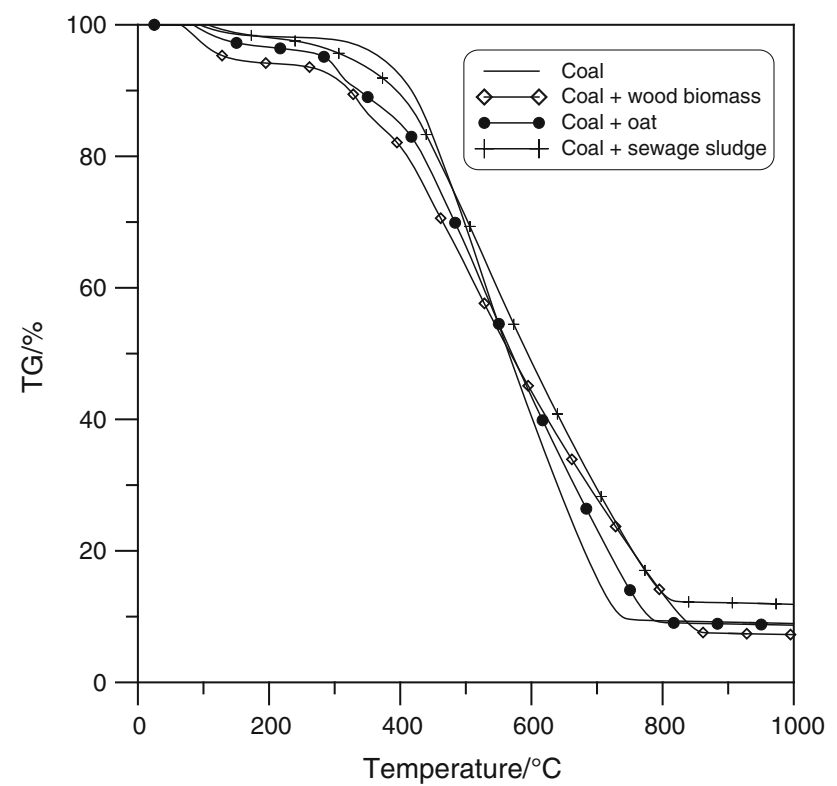

Fig. 12 Co-combustion TG curves for $90 \%$ C-10\% WB, $90 \%$ $\mathrm{C}-10 \% \mathrm{O}, 90 \% \mathrm{C}-10 \% \mathrm{SS}$, and combustion TG curve for coal, heating rate $40{ }^{\circ} \mathrm{C} \mathrm{min}^{-1}$

a reference. The coal shows typical combustion profiles, with the main peak ranging between 300 and $700{ }^{\circ} \mathrm{C}$ with a maximum mass loss rate at $519^{\circ} \mathrm{C}$, the result of thermal decomposition and loss of volatiles, as well as char gasification. The $10 \mathrm{wt} \%$ addition of renewable fuel to coal behaves similarly to coal, although some differences were noted. For the wood biomass and coal mixture, additional peaks were observed at 342 and $476{ }^{\circ} \mathrm{C}$. The maximum mass

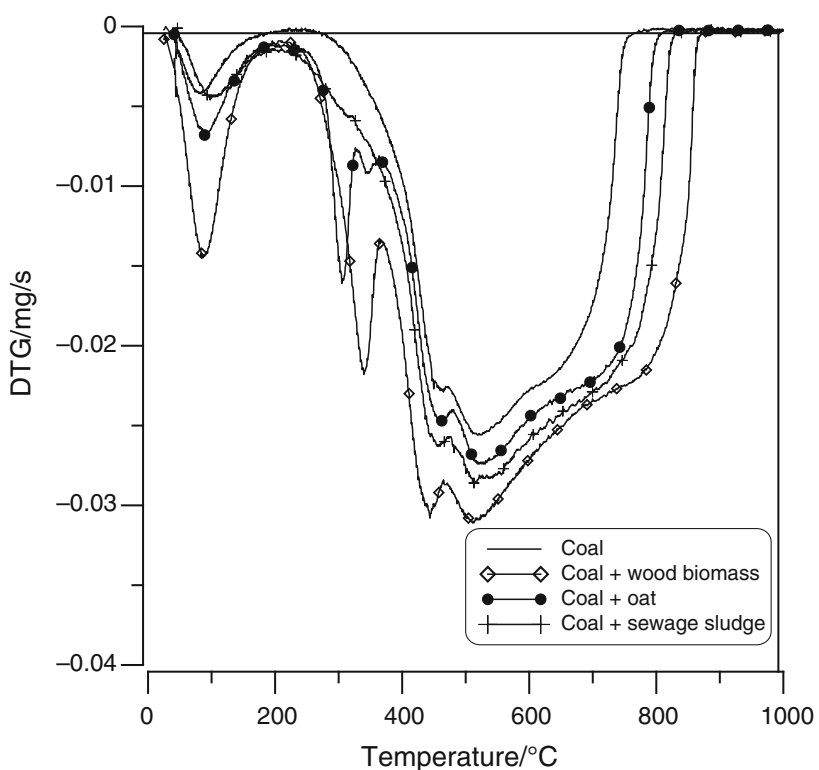

Fig. 13 Co-combustion DTG curves for $90 \% \mathrm{C}-10 \% \mathrm{WB}, 90 \%$ $\mathrm{C}-10 \% \mathrm{O}, 90 \% \mathrm{C}-10 \% \mathrm{SS}$, and combustion TG curve for coal, heating rate $40{ }^{\circ} \mathrm{C} \min ^{-1}$

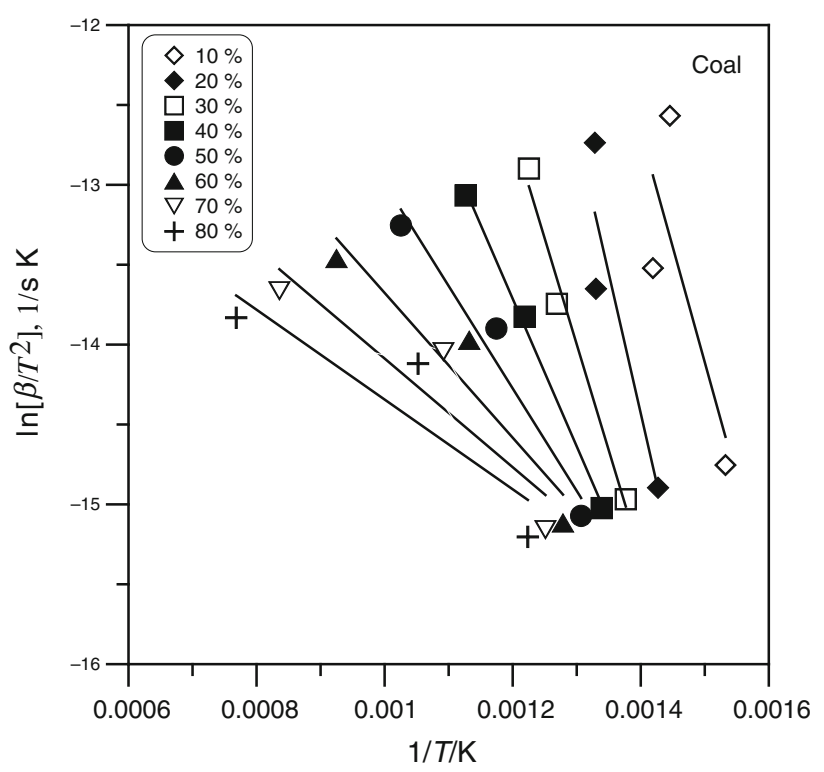

Fig. 14 Curves for fitting to kinetic model proposed by KissingerAkahira-Sunose to various conversion percentage for coal

loss rate for all mixtures was c.a. $513{ }^{\circ} \mathrm{C}$, which was higher than for pure coal.

Kinetic analysis

Figures $14,15,16$ and 17 show the plots of $\ln \left(\beta / T^{2}\right)$ via $1 / T$ for different percentages of conversion degrees ( $\alpha=0.1-0.8$ ) corresponding to the combustion of coal, wood biomass, oat and sewage sludge, straight lines with the no regular coefficient were obtained. As it may be seen, there 


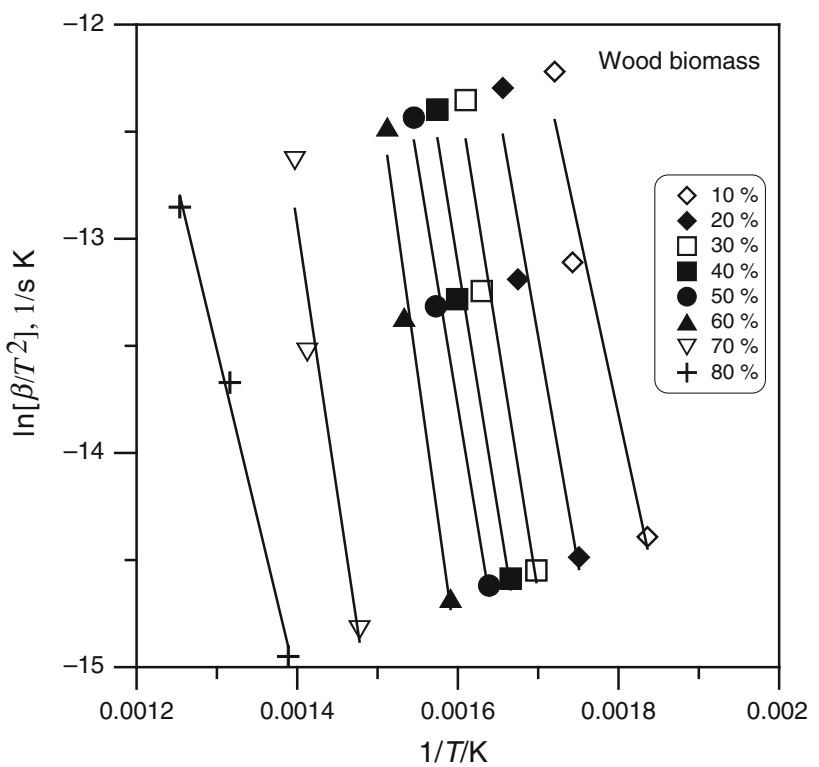

Fig. 15 Curves for fitting to kinetic model proposed by KissingerAkahira-Sunose to various conversion percentage for wood biomass

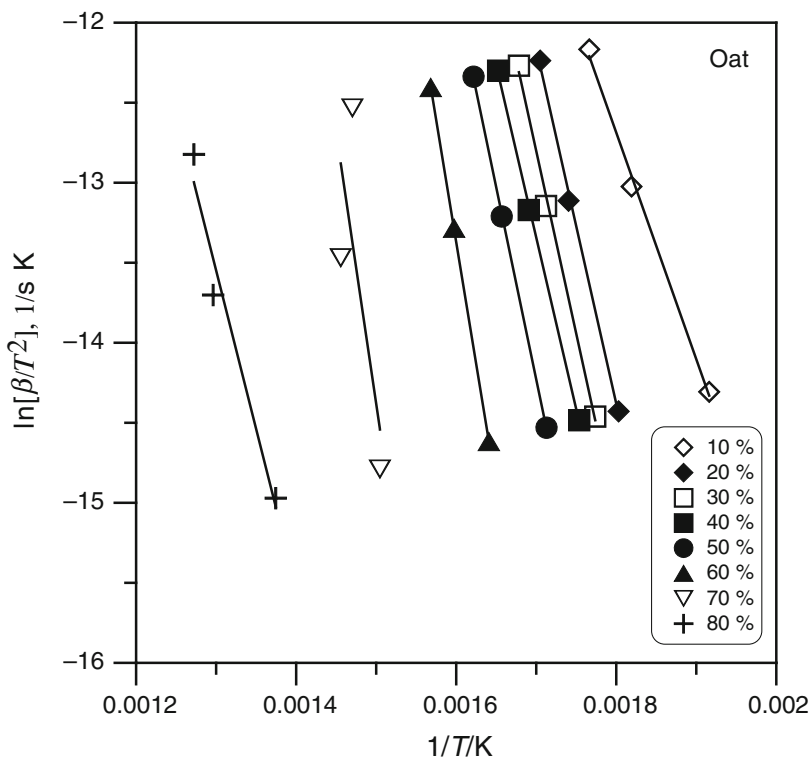

Fig. 16 Curves for fitting to kinetic model proposed by KissingerAkahira-Sunose to various conversion percentage for oat

is linearity for studied conversion percentage so the energy activation $E_{\mathrm{a}}$ may be calculated from the corresponding slope according with kinetic method used. The apparent activation energy was obtained from the slope. Table 4 shows the values of $E_{\mathrm{a}}$ calculated by KAS method. The activation energies for coal were in the range of 21.1 $145.7 \mathrm{~kJ} \mathrm{~mol}^{-1}$, for wood biomass $81.1-223.1 \mathrm{~kJ} \mathrm{~mol}^{-1}$ and for oat $11.9-282.5 \mathrm{~kJ} \mathrm{~mol}^{-1}$. From all studied fuels, the coal had lower activation energy than biomasses or sewage sludge. It can be concluded that fuel with less complex



Fig. 17 Curves for fitting to kinetic model proposed by KissingerAkahira-Sunose to various conversion percentage for sewage sludge

Table 4 Values of activation energy $E_{\mathrm{a}}$ obtained by KAS method for coal, wood biomass, oat and sewage sludge

\begin{tabular}{lllll}
\hline$\alpha$ & $\left.\begin{array}{l}\text { Coal }\left(E_{\mathrm{a}} /\right. \\
\mathrm{kJ} \mathrm{mol}\end{array}{ }^{-1}\right)$ & $\begin{array}{l}\text { Wood biomass } \\
\left(E_{\mathrm{a}} / \mathrm{kJ} \mathrm{mol}^{-1}\right)\end{array}$ & $\begin{array}{l}\text { Oat }\left(E_{\mathrm{a}} /\right. \\
\left.\mathrm{kJ} \mathrm{mol}^{-1}\right)\end{array}$ & $\begin{array}{l}\text { Sewage sludge } \\
\left(E_{\mathrm{a}} / \mathrm{kJ} \mathrm{mol}^{-1}\right)\end{array}$ \\
\hline 0.1 & 119.91 & 143.99 & 117.68 & 29.64 \\
0.2 & 145.69 & 177.65 & 184.50 & 109.16 \\
0.3 & 110.19 & 195.06 & 189.66 & 136.43 \\
0.4 & 76.85 & 191.94 & 178.60 & 150.45 \\
0.5 & 53.32 & 188.27 & 199.64 & 146.80 \\
0.6 & 37.67 & 223.07 & 253.49 & 161.03 \\
0.7 & 28.26 & 208.41 & 282.52 & 122.00 \\
0.8 & 23.36 & 129.61 & 164.75 & 87.32 \\
\hline
\end{tabular}

composition combustions better. The similarity of activation energies of wood biomass and oat results of the nature of these fuels.

\section{Conclusions}

The combustion and co-combustion characteristics of commonly used biomass fuels, sewage sludge and coal were studied at different heating rates under air atmosphere. The elementary and proximate analysis of biomass and sewage sludge showed the differences between these materials. Consequently, the corresponding TG and DTG curves were also dissimilar, especially the temperatures of maximum 
mass loss rate. Activation energy was obtained by KAS model. The experimental results showed that kinetic parameters are in good agreement, and used calculated model can better understand the combustion process. Combustion characteristics of the studied fuels by thermogravimetric analysis and the gas composition analysis from mass spectrometry showed, respectively, the quantitative and qualitative behaviour of these fuels. From this perspective, this study has shown that TG and MS are very useful tools for an initial and quick assessment of these fuels when planning their co-combustion in existing power plants.

Co-combustion of biomass and sewage sludge with alternative fuels is a good and promising waste management alternative. However, it is only with the addition of small amounts of alternative fuels in relation to the total mass of burned fuel that the method does not require additional energy supply.

Acknowledgments The authors are grateful to the Polish Ministry of Science and Higher Education for its financial support, Grant AGH 15.11.110.088.

Open Access This article is distributed under the terms of the Creative Commons Attribution License which permits any use, distribution, and reproduction in any medium, provided the original author(s) and the source are credited.

\section{References}

1. Demirbas A. Combustion characteristics of different biomass fuels. Prog Energy Combust Sci. 2004;30:219-30.

2. Jenkins BM, Baxter LL, Miles TR Jr, Miles TR. Combustion properties of biomass. Fuel Process Technol. 1998;54:17-46.

3. Senneca O. Kinetics of pyrolysis, combustion and gasification of three biomass fuels. Fuel Process Technol. 2007;88:87-97.

4. Darvell LI, Jones JM, Gudka B, Baxter XC, Saddawi A, Williams A, Malmgren A. Combustion properties of some power station biomass fuels. Fuel. 2010;89:2881-90.

5. Kastanaki E, Vamvuka D. A comparative reactivity and kinetic study on the combustion of coal-biomass char blends. Fuel. 2006;85:1186-93.

6. Williams A, Pourkashanian M, Jones JM. Combustion of pulverised coal and biomass. Prog Energy Combust Sci. 2001;27:587-610.

7. Magdziarz A, Wilk M, Zajemska M. Modelling of pollutants concentrations from the biomass combustion process. Chem Process Eng. 2011;32:423-33.

8. Directive 2009/28/EC of the European Parliament and of the Council of 23 April 2009 on the promotion of the use of energy from renewable sources and amending and subsequently repealing Directives 2001/77/EC and 2003/30/EC (Text with EEA relevance).

9. The National Urban Wastewater Treatment Program. Regulation of the Ministry of Environment, Republic of Poland, Warsaw; 2003.

10. Magdziarz A, Wilk M, Kosturkiewicz B. Investigation of sewage sludge preparation for combustion process. Chem Process Eng. 2011;32:299-309.
11. Werther J, Ogada T. Sewage sludge combustion. Prog Energy Combust Sci. 1999;25:55-116.

12. Otero M, Diez C, Calva LF, Garcia AI, Moran A. Analysis of the co-combustion of sewage sludge and coal by TG-MS. Biomass Bioenergy. 2002;22:319-29.

13. Varol M, Atimtay AT, Bay B, Olgun H. Investigation of cocombustion characteristics of low quality lignite coals and biomass with thermogravimetric analysis. Thermochim Acta. 2010;510:195-201.

14. Muthhuraman M, Namioka T, Yoshikawa K. Characteristics of co-combustion and kinetic study on hydrothermally treated municipal solid waste with different rank coal: a thermogravimetric analysis. Appl Energy. 2010;87:141-8.

15. Hanimin X, Xiaoqian M, Kai L. Co-combustion kinetics of sewage sludge with coal and coal gangue under different atmospheres. Energy Convers Manag. 2010;51:1976-80.

16. Yi Q, Qi F, Cheng G, Zhang Y, Xiao B, Hu Z, Liu Sai H, Xu S. Thermogravimetric analysis of co-combustion of biomass and biochar. J Therm Anal Calorim. 2012. doi:10.1007/s10973012-2744-1.

17. Vamvuka D, Karouki E, Sfakiotakis S. Gasification of waste biomass chars by carbon dioxide via thermogravimetry. Fuel. 2011;90:1120-7.

18. Skreiberg A, Skreberg O, Sandquist J, Sorum L. TGA and macroTGA characterisation of biomass fuels and fuel mixtures. Fuel. 2011;90:2189-97.

19. Gomez CJ, Meszaros E, Jakab E, Velo E, Puigjaner L. Thermogravimetry/mass spectroscopy study of woody residues and herbaceous biomass crop using PCA techniques. J Anal Appl Pyrolysis. 2007;80:416-26.

20. Magdziarz A, Wilk M. Thermogravimetric analysis of coal and biomass co-combustion in modified atmosphere (in Polish). Energy Mark. 2011;6:45-50.

21. Stenseng M, Zolin A, Cenni R, Frandsen F, Jensen A, DamJohansen K. Thermal analysis in combustion research. J Therm Anal Calorim. 2001;64:1325-34.

22. Calvo LF, Sanchez ME, Moran A, Garcia AI. TG-MS a technique for a better monitoring of the pyrolysis, gasification and combustion of two kinds of sewage sludge. J Therm Anal Calorim. 2004;78:587-98.

23. Villanueva M, Proupin J, Rodrigez-Aňón JA, Fraga-Grueiro L, Salgado J, Barros N. Energetic characterization of forest biomass by calorimetry and thermal analysis. J Therm Anal Calorim. 2011;104:61-7.

24. Zhai Y, Peng W, Zeng G, Fu Z, Lan Y, Chen H, Wang C, Fan X. Pyrolisis characteristics and kinetic of sewage sludge for different size and heating rates. J Therm Anal Calorim. 2012;107:1015-22.

25. Sebestyěn Z, Lezsovits F, Jakab E, Vărhegyi G. Correlation between heating values and thermogravimentric data of sewage sludge, herbaceous crops and wood smaples. J Therm Anal Calorim. 2012;110:1501-9.

26. Altun NE, Hicyilmaz C, Kök MV. Effect of particle size and heating rate on the pyrolysis of Silopi asphaltite. J Anal Appl Pyrolysis. 2003;67:369-79.

27. Iscan AG, Kök MV, Bağci AS. Kinetic analysis of central anatolia oil shale by combustion cell experiments. J Therm Anal Calorim. 2007;88:653-6.

28. Ozbas KE, Hicyilmaz C, Kök MV, Bilgen S. Effect of clearing prcocess on combustion characteristics of lignite. Fuel Process Technol. 2000;64:211-20.

29. Kök MV. Effect of clay on crude oil combustion by thermal analysis techniques. J Therm Anal Calorim. 2006;84:361-366.

30. Taş S, Yürüm Y. Co-firing of biomass with coals. J Therm Anal Calorim. 2012;177:293-8. 